\title{
STUDENTS' ABILITY IN WRITING APPLICATION LETTER AT FOURTH SEMESTER ASM PERSADA BUNDA PEKANBARU
}

\author{
Lia Diana \\ Akademi Bahasa Asing (ABA) Persada Bunda Pekanbaru \\ E-mail: liadiana12@gmail.com
}

\begin{abstract}
The purpose of this research was to find out the effectiveness of application letters to improve the students writing skills. The research intent onto the students' ability English functional writing, especially in writing application letter at the fourth semester ASM Persada Bunda Pekanbaru. This research belongs to a descriptive study, specifically descriptive qualitative. To find out the students' ability in writing an application letter, the researcher used a written text where the students should write their application letter and identify the basics elements or the format of the application letter. Students writing were assessed based on the format of the business letter especially for application letter which consists of Heading, Inside Adress, Salutation, Body, Closing, and Signature. After collecting the data, the researcher analyzed them by describing their ability to writing an application letter and its basic elements inside. As a result, the researcher found that most of the students were easily identified Salutation, Body, and Signature. Three students could not identify Salutation, three students could not identify Heading and Inside Adress, one student could not identify Closing. The research determined that application letter could improve the students writing's skill. From the data above, it can be said that the ability of ASM's students to writing application letters is good, they were easily in identified Salutation, Body, and Signature.
\end{abstract}

Keywords: Application letter, Writing Ability

\begin{abstract}
Abstrak
Tujuan dari penelitian ini adalah untuk menemukan keefektifan surat lamaran kerja dalam meningkatkan kemampuan menulis mahasiswa. Penelitian ini bermaksud untuk mengetahui keahlian menulis bahasa inggris mahasiswa secara fungsional, khususnya dalam menulis surat lamaran kerja pada mahasiswa semester IV Akademi Sekretaris dan Manajemen Persada Bunda Pekanbaru. Penelitian ini merupakan penelitian desskriptif, khususnya deskriptif kualitatif. Untuk mengetahui kemampuan siswa dalam menulis surat lamaran kerja, peneliti menggunakan teks tertulis dimana mahasiswa harus menulus surat lamaran kerja mereka sendiri dan mengidentifikasi poin-poin dasar atau format penulisan surat lamaran kerja. Tulisan mahasiswa dinilai berdasarkan format penulisan surat bisnis khususnya format penulisan surat lamaran kerja yang terdiri dari Kepala Surat (Heading), Alamat Penerima Surat (Inside Adress), Salam Pembuka (Salutation), Badan Sura (Body of Letter), Salam Penutup (Closing), dan Tandatangan (Signature). Setelah mengumpulkan data, peneliti menganalisanya dengan menjelaskan kemampuan mereka dalam menulis surat lamaran kerja
\end{abstract}


sesuai dengan format yang terdapat didalamnya. Hasilnya, peneliti menemukan sebagian mahasiswa dapat dengan mudah mengidentifikasi Salam Pembuka, Badan Surat, dan Tandatangan. Tiga mahasiswa tidak dapat menidentifikasi Salam Pembuka, tiga mhasiswa tidak dapat mengidentifikasi Kepala Surat dan Alamat Penerima Surat, satu mahasiswa tidak dapat mengidentifikasi Salam Penutup. Penelitian ini menunkukan bahwa penggunaan surat lamaran kerja dapat meningkatkan kemampuan menulis mereka. Dari data diatas dapat dikatakan bahwa kempauan menulis surat lamaran kerja mahasiwa Akademi Sekretaris dan Manajemen Persada Bunda Pekanbaru dapat dikatakan bagus. Mereka dapat dengan mudah menidentifikasi Salam Pembuka, Badan Surat, dan Tandatangan.

Kata Kunci: Surat Lamaran Kerja, Kemampuan Menulis

\section{INTRODUCTION}

English is one of the international languages which is used by most people around the world. In a global era, people are expected to master English so that they can communicate with other people who live in other countries. As a tool of international communication, it should be learned by people who live in a country that uses English as a foreign language, including Indonesia. To support Indonesian people to be able to communicate with other people around the globe, the Indonesian government incorporates English into its educational curriculum as one of its compulsory subjects starting from junior high school. Hence, it is hoped that there will be a great chance for
Indonesian learners to improve their English communication competence.

English is a very important role in Indonesia. As a developing country, it needs to learn more new things from developed countries, such as a new advanced idea, research findings, and experiments. It is undeniable that these things are very important for national development. English happens to be the native language of the developed countries whose economy, technology, and politics are very influential. The study of English continues to occupy an important place in our educational curriculum. English is regarded as the first foreign language to be taught at elementary school as local content, at secondary school as a compulsory 
subject, and the university as an additional subject

Moreover, we live in a modern age, therefore, everything concerning developments such as technology, economics, education, politics, and many more in our country needs English skills. This assumption is based on the fact that most scientific books are written in English. It cannot be denied that English is a key tool for scientists to study all those books in improving their insight and knowledge related to their disciplines.

In ASM Persada Bunda especially for the secretary program, the students study some subjects that relate in English. Secretary Program is a program that is ready to be taught skills and create employment candidates who are competent, competitive, and independent in the secretarial field. Expertise in this program will educate students to be able to handle the administration of the company which includes handling incoming and outgoing mail, letters agenda, and schedule management.
The students learn textbooks contain a lot of information related to the subjects. To access this information, therefore they need sufficient knowledge of English. Especially, they should have the skills of writing because they should write many letters forms in English, that is why the writing skill is important to be mastered.

Based on the observation during the teaching and learning process, the writer found that some learners still had low writing skills in class especially in writing application letters. It was proven when the researcher taught a learning process in a class. They faced some writing problems which caused the learners had difficulties in comprehending information presented in the textbooks.

Arvani and Tabriz stated in their journal that since the social and interpersonal aspects of language are of great significance for native speakers of English, any mismatch of linguistic forms such as interferences caused by Iranian writers may lead to misunderstanding and annoyance. Consequently, ESP (English for 
Specific Purposes) teachers should try to familiarize the learners of business English with social features and interactional aspects of the language and direct the learners to use the social sub-skills and pragmatic elements in their business letters.

Based on the explanations above, the writer concluded that the students should master four language skills, especially writing skills. They are required to be good workers and mastering their field. Also, the students are taught to be experts in their respective fields of work from a very young age. So that they are expected to compete in the field they pursue both at local and international level.

There are several different common types of business letters, they are letters of order, request, application, and recommendation.

\section{a. Order Letter}

Probably most of the business letter is to order goods and materials. It is important that the letter clearly states the exact name of the merchandise, the price, and the amount of payment being sent. b. Request Letter

It is often necessary to write letters asking for information or advice.

c. Application Letter

Usually, business and professional people are hired based on letters of application and personal interview. Quite often an appointment is made for a personal interview only after a letter of application has been received. It is a very important letter for both the sender and the receiver.

d. Recommendation Letter

Often people are called on two write letters of recommendation for friends or colleagues. It is always best to address the letter to a specific individual, but, if it is a general recommendation, it is correct to use the expression to whom it may concern in place of a more specific salutation.

According to A John Carey, there are six basic styles of business letters as follow:

a. Block

The Block format is by far the simplest. Every part of the letter starts at the left margin, with spaces 
between each part. It has a professional look to it. The order for the parts of the letter is the date, file number, inside address, attention line, salutation, subject line, body, complimentary close, signature, typed name and additional information.

\section{b. Modified block}

Like the Block, the Modified Block has the advantage of separating paragraphs so that each one stands out. The spacing between sections remains the same as in the Block. The date, signature, and closing are placed to the right, thus allowing them to stand out. The complimentary close and the signature are aligned and placed near the center of the letter, two spaces below the last paragraph.

c. Modified semi-block

Modified Semi-Block is the same as the Modified Block except that the paragraphs are indented five spaces. All spacing remains the same. It is the same as the Modified Block except that the paragraphs are indented five spaces. All spacing remains the same.

d. Simplified
The focus of the letter is on the body and what is to be said. The spacing is the same as the Block format.

e. Hanging indented

Its main advantage is that it calls attention to the body and each of the paragraphs. Spacing between the lines and sections is the same as in previous examples.

f. Memo

The sixth form of the letter is the Memo. Though used primarily as an interoffice communication, it is occasionally used as a business letter format. The top of the Memo indicates the date, the name(s) of the recipient(s), the name(s) of the sender(s) and the subject. The abbreviation "RE" is sometimes used instead of "Subject". This information is placed at the left margin. The body of the Memo is in Block form. A signature and additional information are optional. The signature is often placed near the center with additional information at the left margin. 
There is a format in writing a business application letter. According to George and Julia, the correct form as follow:

\section{a. Heading}

The heading or return address of a business letter is similar to that used on personal letters: street, city, state, zip code, country, and date. Usually, the block form is used. Use a comma after the name of the city and the day of the month.

b. Inside address

The inside address is the name of a company or business the letter is being written to. It includes the street address, city, state, zip code, and country. It is the same address that appears on the envelope. Envelopes are not kept in the business file; the letter must carry all pertinent information.

\section{c. Salutation}

The greeting part of a business letter is more formal than that of a personal letter. The salutation is followed by a colon. These are suitable salutations:

Dear Madam:

Dear Sir:

Dear Sir/Madam:
Dear Mrs. Itgen:

Dear Mr. Modian:

Dear Ms. Wartsky:

If the sender is writing to a firm and does not know the name of any particular person to whom to address the letter, Dear Sir / Madam is commonly used. However, there is a growing tendency in such cases to omit the salutation altogether and to begin the letter immediately after the inside address.

d. Body

The business is discussed in the body of the business letter. It should be brief, well stated, and easy to read. The importance of brevity and directness cannot be overstated. Business offices receive large numbers of letters daily. If they are all to be handled promptly, no time can be wasted. Business letters, therefore, must be succinct and to the point.

e. Closing

The closing of a business letter is similar to that of a personal letter. The first word is capitalized. The closing is followed by a comma. Here are some useful closing expressions. 
Sincerely,

Sincerely yours,

Very truly yours,

Yours truly,

Yours respectfully,

f. Signature

The sender's name should be written the way the company is to address the return letter. If the sender wishes to be addressed by a personal or professional title, it should be written after the name, usually in parentheses: (M.D), (Ph.D.), (Mrs.), (Miss), (Ms.), etc.

\section{METHOD}

This study was descriptive research. It was intended to find out the students' skill by writing an application letter. Best (2005: 25) said that descriptive research describes the situation or thing that exists at the same time as the study. It means that this research did not tend to find a new theory but only verify and describe the existing one. By implementing the quantitative approach, it attempted to find out the students' mastery in writing an
In other words, John A. Carey obtained that there are many parts to the business letter - some required, some optional.The parts of the business letter are letterhead or heading, date, file number (optional), confidential (optional), inside address, attention line (optional), salutation (optional), subject line (optional), body of the letter, complimentary close (optional), signature, added information (optional), postscript (optional), and mailing instructions (optional).

application letter to improve their writing skills.

In this research, the data could be collected by using a test. The test was a piece of a job vacancy that will be analyzed by the student and also the students should write an application letter based on the job vacancy.

The purpose of this research is to find out the effectiveness of the Application Letter to improve students' writing ability. By Application Letter, the researcher expects to improve students' writing 
ability. In elaborating a theoretical rationale for the natural approach, the lecturer did her teaching enjoyably.

\section{FINDING AND DISCUSSION}

Theoretically, it was expected those the results of the study give a contribution to support the theory on teaching English as a foreign language, especially for the writing teacher. Practically, the result of this study was expected to give a contribution to the English teachers, especially in teaching writing. Moreover, the result of the study was expected to provide empirical data about students' abilities in writing an application letter. Besides, the study also helped the students to know their abilities in writing a letter.

The purpose of this research is to find out the effectiveness of the Application Letter to improve students' writing ability. By Application Letter, the researcher expects to improve students' writing ability. In elaborating a theoretical rationale for the natural approach, the lecturer did her teaching enjoyably.
After counting and calculating the percentage of each score, then it was compared with the standard mastery to determine whether a student was mastery to do the test or not.

The standard of mastery for individual mastery of the learning process is $75 \%$ of the test given. It means that if a student can answer $75 \%$ of the test correctly, s/he was categorized as mastery, and if it is below $75 \%$ s/he was categorized as non-mastery. Then, if $50 \%$ of the sample gets $75 \%$ or more, it means that students of ASM Persada Bunda were categorized as mastery, but if less than that, they were categorized as non-mastery.

Next, the percentage of each score was compared with the standard of level mastery. The classification of the score levels used as a criterion in determining the level of students' mastery of the test. The level of mastery consulted with the following table. 
Table 1.The Classification of Level of Mastery

\begin{tabular}{|c|c|}
\hline Score & Category \\
\hline $80-100$ & Excellent \\
\hline $60-79$ & Good \\
\hline $40-59$ & Fair \\
\hline $0-39$ & Poor \\
\hline
\end{tabular}

The data of this research were the students' scores in their writing comprehension to write an application letter. The students' mastery in writing six basic elements of application letter can be seen in the following table :

Table 2. The students' comprehension in identify six basic elements of

\begin{tabular}{|c|c|c|c|c|c|c|}
\hline \multicolumn{7}{|c|}{ application letter } \\
\hline 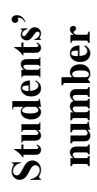 & 急 & 莺 & & 胥 & 这 & 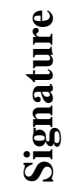 \\
\hline 1 & $\sqrt{ }$ & $\sqrt{ }$ & $\sqrt{ }$ & $\sqrt{ }$ & $\sqrt{ }$ & $\sqrt{ }$ \\
\hline 2 & & $\sqrt{ }$ & $\sqrt{ }$ & $\sqrt{ }$ & $\sqrt{ }$ & $\sqrt{ }$ \\
\hline 3 & & & & $\sqrt{ }$ & & $\sqrt{ }$ \\
\hline 4 & $\sqrt{ }$ & $\sqrt{ }$ & $\sqrt{ }$ & $\sqrt{ }$ & & $\sqrt{ }$ \\
\hline 5 & & & $\sqrt{ }$ & $\sqrt{ }$ & & $\sqrt{ }$ \\
\hline
\end{tabular}

From the table, it can be seen not all of the students could identify six basic elements of the application letter. Most of them got difficulties to identify Inside Adress, Closing, and Heading. Many of them could identify the Salutation, Body, and Signature.
Most of the students were easily identified salutation, body, and signature. Three students could not identify Heading and Inside Adress, one student could not identify Salutation, three students could not identify Closing. 
Table 3. The Classification of Level of Students' Mastery

\begin{tabular}{|c|c|}
\hline Students Number & Category \\
\hline Student 1 & Excellent \\
\hline Student 2 & Good \\
\hline Student 3 & Fair \\
\hline Student 4 & Good \\
\hline Student 5 & Good \\
\hline
\end{tabular}

\section{CONCLUSION}

In this section, the writer would like to give a conclusion and suggestion about the result of the study. The conclusion of the study was the answer to the problem of the study as stated in chapter I which the finding was based on the result of the data analysis. The suggestions are expected to make better improvement and motivation for students, teachers and the next researchers. So, almost all of the students are good at writing an application letter. Concerned with the conclusion, the writer would like to propose some suggestions that hopefully would be useful and valuable for the fourth-semester students of ASM Persada Bunda Pekanbaru. The writer recommended the students to learn more in writing, especially in functional writing because it will help the students infill the purpose of their assignment and their language skill in the future.

\section{REFERENCES}

Arikunto, Suharsimi., Prosedur Penelitian: Suatu pendekatan Praktek, Jakarta: PT Rineka Cipta, 2006.

Arvani, Mansour., and Tabriz, 'A Discourse Analysis of Business Letters Written By Iranians \& Native Speakers', The Asian ESP Journal June 2006, Vol.1. Article 2.

Ary, Donal., et al., Introduction to Research in Education, Wadsworth, 2010.

Brown, Douglas H., Principles of Language Learning and Teaching Fourth Edition, New York: Longman Inc., 2000.

Brown, Douglas H., Teaching by Principles: an Interactive Approach to Language Pedagogy Second Edition, Longman. 
Burdová, Veronika., English for Specific Purposes (Tourist Management and Hotel Industry), Masaryk University Faculty of Education

Department of English Language and Literature, 2007.

Carey, John A., Business Letter for Busy People, 4th Edition, The Caree Press, USA, 2002.

D, Gould. E., dkk., The Act of Writing, New York: Random House, 1989.

Dierkes, Meinolf; Hans Weiler and Ariane Antal., Comparative Policy Research. Gower. 1987.

Donn, Byrne., Teaching Writing Skills, England: Long Man 1979.

Dulay, Heidi., et al. Language two. New york: oxford university press, 1982.

Fauziati, Endang., Teaching English as a Foreign Language. Surakarta: Muhammadiyah University Press, 2002.

George E. Whison and Julia M. Burks., Let's Write English Revised Edition, Van Nostrand Reinhold Ltd.
Harmer, Jeremy., How to Teach Writing, England: Longman, 2007.

Herlina, 'The Effectiveness Of Using Concept Mapping In Writing Recount Paragraph Toward The Students' Writing Ability At The Tenth Year Of Sma Muhammadiyah 1 Tumbang Samba Katingan Tengah', State Islamic college of Palangka Raya Department of Education Study Program of English Education, 2012 